\title{
Ilmastonmuutos ja maaseutu (ILMASE) -hanke: tutkimustietoa ja verkostoitumista maaseudun toimijoille
}

\author{
Sari Himanen ${ }^{1}$, Karoliina Rimhanen ${ }^{2}$, Hanna Mäkinen ${ }^{3}$, Miia Kuisma ${ }^{4}$ ja Helena Kahiluoto ${ }^{5}$ \\ ${ }^{1}$ MTT, Kasvintuotannon tutkimus, Lönnrotinkatu 5, 50100 Mikkeli, sari.himanen@mtt.fi \\ ${ }^{2}$ MTT, Kasvintuotannon tutkimus, Latokartanonkaari 9,00790 Helsinki, karoliina.rimhanen@mtt.fi \\ ${ }^{3}$ MTT, Kasvintuotannon tutkimus, Lönnrotinkatu 5, 50100 Mikkeli, hanna.makinen@mtt.fi \\ ${ }^{4}$ MTT, Kasvintuotannon tutkimus, Lönnrotinkatu 5, 50100 Mikkeli, miia.kuisma@mtt.fi \\ ${ }^{5}$ MTT, Kasvintuotannon tutkimus, Lönnrotinkatu 5, 50100 Mikkeli, helena.kahiluoto@mtt.fi
}

\section{Tiivistelmä}

Ilmastonmuutos on yhä keskeisempi osa Suomenkin maa- ja elintarviketalouden arkipäivää. Maaseutuyrittäjät ovat lisääntyvän tietomäärän ja ilmastonmuutoskytkentäisen hanketarjonnan ympäröimiä, mutta harvalle on kirkastunut millaisia ilmastonmuutoksen hillintä- ja sopeutumistoimia tiloilla käytännössä voitaisiin kehittää ja toteuttaa kannattavasti. Kannattavuus mietityttää monia ja uskomuksia ympäristö- ja talousnäkökulmien vastakkainasettelusta löytyy edelleen. Moni ei kykene hahmottamaan miten tie kestävään ja taloudellisesti kannattavaan toimintaan voisi lähteä ilmastonmuutosta paremmin ennakoivista toimista. Valtakunnallinen tiedonvälityshanke "Ilmastonmuutos ja maaseutu (ILMASE)" pyrkii välittämään ilmastonmuutostietoa maaseudun toimijoille käytännönläheisesti, lähestyen aihetta myös taloudellisen kannattavuuden parantamisen ja maaseudun kehittämisen kannalta. Ilmastonmuutokseen varautumisessa korostuvat yhä enemmän taloudelliset riskit (ääri-ilmiöiden lisääntyminen) ja innovaatiot (uudet viljelykasvit ja uusiutuvan energian liiketoimintamahdollisuudet). Ilmastonmuutoskommunikaatiosta tekee vaikeaa ihmisten subjektiivinen tapa nähdä oikeutettuina itselle nykyhetkessä hyödylliset lyhytnäköiset toimintatavat, sekä erot tutkijoiden, päätöksentekijöiden ja viljelijöiden käsityksissä ilmastonmuutoksen vaikuttavuudesta ja keinoista sopeutua. Tiedotus ilmastonmuutoksen ennustamisen epävarmuudesta, hillintäpoliittisten neuvottelujen hankaluuksista ja sään ääreistymisestä ja hitaasta muuttumisesta voi jopa heikentää toimijoiden reagoimista ilmastonmuutokseen. Ilmastonmuutoksen hillitseminen ja sopeutuminen Suomessa kaipaa toimijatasojen välistä kommunikaatiota, joka muokkaa syvällä olevia asenteita ja helpottaa epävarmuutta. ILMASE-hanke selvitti kyselyn avulla käsityksiä maaseutuyrittäjien ilmastonmuutostiedon tarpeista, esteitä tiedon kiinnostavuudelle ja käytäntöön viemiselle ja kannustimia tuoda ilmastonmuutokseen varautuminen lähemmäksi käytäntöä. Maaseutuyrittäjät olivat vastaanottavaisimpia ilmastonmuutoksen taloudellisia vaikutuksia avaavalle käytännön tiedolle sekä käytännönläheisille keinoille, jotka olisivat sekä ympäristöä vähemmän kuormittavia että taloudellisesti kannattavia. Tutkijoiden haluttiin tiedostavan entistä paremmin tarpeen esittää ja suodattaa faktatietoaan kohderyhmän tarpeisiin. Myös epävarmuus ilmastotiedossa on hyvä tiedostaa, mutta sen jatkuva korostaminen ei kannusta toimintaan. Toivottiin perusteltua tutkimustietoa ilmastonmuutoksen merkityksestä, positiivisessa hengessä ja keskustellen. ILMASE-hanke järjestää vuonna 2012 alueellisia työpajoja ja kokoaa niiden aineistot verkkosivustolleen keskusteluun. Mukaan vuoropuheluun ilmastonmuutokseen varautumisesta kutsutaan maaseutuyrittäjiä, tutkijoita, neuvojia, maaseudun kehittäjiä ja päätöksentekijöitä.

\section{Asiasanat}

ilmastonmuutos, maatalouden kannattavuus, sopeutumistoimet, tiedonvälitys 


\section{Johdanto}

Ilmasto on monimutkaisimpia ja silti arkipäiväisimpiä asioita maailmassa. Säätila puhututtaa joka päivä ja ilmanlaatu on keskeisimpiä ympäristöindikaattoreita. Ilmastonmuutoksen vaikutusten monimutkaisuuden ja ilmiön globaaliuden takia se herättää kiivasta keskustelua ja on eittämättä aikamme keskeisimpiä mielipiteitä jakavia aiheita. Ilmastonmuutos koskettaa tänä päivänä jo jokaista toimialaa Suomessa (Kimpanpää 2009) ja sektorikohtaista sopeutumistoimien suunnittelua on tehty jo pitkään myös maa- ja elintarviketaloudessa (Maa- ja metsätalousministeriö 2011). Maatalous on säälle herkimpiä toimialoja ja usein myös hyvin energiariippuvaista.

Ilmastonmuutostiedon määrä on kasvanut enenevästi etenkin kansainvälisen ilmastopaneelin IPCC:n kokoamisesta alkaen. Sekä vaikutusten, hillinnän että sopeutumisen osalta tietopääoma on suuri, mutta tiedon soveltaminen käytäntöön on kansallisesti ja paikallisesti vielä hyvin rajallista ja riippuvaista asian ajankohtaiseksi kokemisesta itse toimijoiden tasolla. Meillä Suomessa päätöksenteossa ja tutkimuksessa ilmastonmuutos on jo pitkään ollut kasvavia valtateemoja, kun taas käytännön viljelijöistä varsin harva luokittelee asian tänä päivänä heille ajankohtaisimpiin aiheisiin. Tarvittaisiin yhä selkeämpää tiedon suodatusta ja konkretisointia viljelijöiden ilmastonmuutokseen varautumisen tueksi. Viljelijöiltä on tullut viesti, että tiedonpuute ei ole ongelma, mutta sen sovellettavuus ja joskus jopa uskottavuus ristiriitaisten perustelujen vuoksi on.

Ilmastonmuutoskommunikaation vaikeus on huomattu jo ilmiön vaikutusten, niiden suuruuden ja nopeuden kansainvälisessä käsittelyssä (Sterman 2011), vastuunjakokysymysten pohdinnassa (Kriss ym. 2011), alueiden eriasteisen haavoittuvuuden maailmanlaajuisen jakautumisen arvottamisessa (Tavoni ym. 2011) ja sektorikohtaisten hillintätarpeiden keskustelussa. Ilmastonmuutoksen globaali luonne ja sen pitkäkestoiset mutta vielä suurimmassa osassa maailmaa heikosti realisoituvat suorat vaikutukset tekevät ilmiön hahmottamisesta erityisen vaikeaa (Fischhoff 2007). Ihmisluonne on taipuvainen reagoimaan vaikeasti hahmotettaviin asioihin, jotka voivat aiheuttaa lisäkuluja tai vaatia sopeutumista vasta kun on käytännössä pakko. Myös hyvin satunnaiset tekijät, kuten henkilökohtainen kokemus säätilan muutoksista lyhyellä aikavälillä voi vaikuttaa suuresti käsitykseen ilmastonmuutokseen varautumisen kiireellisyydestä (Li ym. 2011). Talous ja ilmasto ovat molemmat suuria ja kompleksisia dynaamisia järjestelmiä, jotka ovat riippuvaisia monen eri toimijatahon muutoksista ja jotka vaikuttavat paikallisesti, kansallisesti ja kansainvälisesti (Sterman 2011).

Pidgeon \& Fischhoff (2011) ehdottavat parhaimmaksi tavaksi välittää ilmastonmuutostietoa seuraavaa: mukana olisi oltava 1) ajantasaisen tutkimustiedon asiantuntijoita tieteellisen pohjan tuottajina (sisältäen mm. ilmasto- ja taloustieteilijöitä, ekologeja, teknisen ja luonnontieteellisen alan tutkijoita, maatalouskontekstissa lisäksi maatalous- ja biotieteilijöitä), 2) päätöksenteon ja politiikan asiantuntijoita tunnistamaan ja koostamaan oleellisimmat seikat käytännön toimien kannalta, 3) yhteiskuntatieteilijöitä ja viestinnän asiantuntijoita tunnistamaan tiedonvälityksen kohderyhmän tarpeita ja käsityksiä, tuomaan kommunikaatioon konkreettisia välineitä ja arvioimaan vuorovaikutuksen onnistumista, 4) projektinhallintaa, joka määrätietoisesti varmistaa tasa-arvoisen kommunikaation, tiedonvälityksen tarkoituksenmukaisuuden ja tulosten viemisen päätöksentekoon asti. Valtakunnallinen Ilmastonmuutos ja maaseutu (ILMASE) -hanke käynnistyi vuoden 2011 alussa ja pyrkii paitsi välittämään ajantasaista ilmastotietoa maaseudun toimijoille niin myös luomaan tällaista vuoropuhelua, jossa huomioidaan toimijoiden tarpeet heti alusta alkaen. Tässä artikkelissa esitetään alustavia tuloksia hankkeessa toteutetusta tiedontarvekyselystä maaseutuyrittäjille, neuvojille, päätöksentekijöille ja aluekehittäjille.

\section{Aineisto ja menetelmät}

ILMASE-hankkeessa toteutettiin syksyllä 2011 kysely ilmastonmuutoksen tietotarpeista, nykyisen ilmastotiedon käytännönläheisyydestä ja sen kiinnostavuutta lisäävistä tekijöistä hankkeen kohderyhmälle eli maaseudun toimijoille. Kysely lähetettiin sähköisesti yhteensä yli 1700 henkilölle. Otanta koostui maaseutuyrittäjistä, jotka toimivat MTK:n toimiryhmissä, ELY-keskusten maaseutuhankkeiden hallintohenkilöistä, maatalouden energiasuunnitelmien tekijöistä, Pro Agrian neuvojista, ja pienestä ryhmästä tutkijoita ja maaseudun kehittäjiä. Henkilöt valikoituvat paitsi työtehtävänsä myös etujärjestöaktiivisuuteensa kautta mukaan. Esitietona kerättiin vastaajan asuinalue (ELY-keskusjaon mukaisesti), ikä (jaottelu: alle 30, 31-40, 41-50, 51-60, yli 60 vuotta) sekä ammattiryhmä (jaottelu: maaseutuyrittäjä, neuvoja, etujärjestötoimija, opettaja/kouluttaja, tutkija, asiantuntija, virkamies tai muu päätöksentekijä, työntekijä, muu). 
Kysely toteutettiin Webropol-ohjelmalla (Webropol 1.0, Webropol Oy) ja siihen sisältyi sekä avoimia kysymyksiä että kvantitatiivisesti analysoitavia monivalintakysymyksiä. Monivalintakysymyksillä pyrittiin kartoittamaan alueellisia ja ammattiryhmäkohtaisia käsityksiä akuuteimmista tiedontarveteemoista ilmastonmuutoksen suoriin ja epäsuoriin vaikutuksiin liittyen. Teemat olivat tutkimusryhmän valitsemia aiheita, joista uskottiin löytyvän tieteellistä asiantuntemusta ja ajantasaista tutkimustietoa Suomesta. Vastaajia pyydettiin arvioimaan myös näiden keskinäistä tärkeyttä. Vastaajilla oli lisäksi mahdollisuus esittää esitetyistä puuttuvia, mutta heistä keskeisiä tiedontarveteemoja. Avoimilla kysymyksillä selvitettiin mm. käytännön esteitä ilmastonmuutostiedon kiinnostavuudelle ja käytäntöön viemiselle maaseutuyrittäjien keskuudessa sekä tiedusteltiin tekijöitä, jotka auttaisivat maaseutuyrittäjää pohtimaan ja hahmottamaan paremmin ilmastonmuutosta osana nykypäivän ja lähitulevaisuuden käytännön toimintaa. Kyselyn tarkempi analyysi valmistuu vuoden 2012 alussa. Tässä artikkelissa esitetään muutamia keskeisimpiä havaintoja ilmastonmuutostiedon kiinnostavuuden ja käytäntöön viemisen haasteiden ja ratkaisuehdotusten osalta. Lisäksi vertaillaan ammattiryhmien käsityksiä kymmenen tutkijaperusteisesti muodostetun teemakokonaisuuden keskinäisestä tiedontarpeen tärkeydestä maaseutuyrittäjien ilmastonmuutokseen varautumisessa.

Kyselyyn vastasi yhteensä 342 henkilöä, joista suurin osa oli maaseutuyrittäjiä (36,4 \% vastaajista), neuvojia (24,9\% vastaajista) ja virkamiehiä tai päätöksentekijöitä $(20,8 \%)$. Alueellisesti eniten vastaajia oli Pohjois-Pohjanmaalta (12\% vastaajista), Etelä-Pohjanmaalta $(8,8 \%)$ ja Hämeestä $(8,8 \%)$ ja vähiten Lapista $(2,9 \%)$ ja Kainuusta (4,7 \%). Kaikkien vastaajien pääikäryhmät olivat 41-50 vuotta (32,4 \% vastaajista) ja 51-60 vuotta (32,2\% vastaajista). Maaseutuyrittäjistä enemmistö oli Pohjois-Pohjanmaalta (16,1 \% vastaajista), Varsinais-Suomesta $(10,5 \%)$ tai Keski-Suomesta $(8,1 \%)$ ja vastaajien ikäjakauma painottui hieman enemmän nuorempiin ikäluokkiin kuin koko aineistossa.

\section{Tulokset ja tulosten tarkastelu}

Maaseutuyrittäjien, neuvojien ja virkamiesten/päätöksentekijöiden käsitykset maaseutuyrittäjien suhteellisesta tiedontarpeesta esitetyistä ilmastonmuutokseen liittyvistä teemoista erosivat selkeimmin hillintätoimien tiedontarpeiden osalta (Kuva 1). Sekä virkamiehet/päätöksentekijät että neuvojat näkivät tämän hetken maaseutuyrittäjien tiedontarpeet hillintäkeinoista suurempina kuin itse maaseutuyrittäjät. Yrittäjät sen sijaan näkivät energiatehokkuuden ja tulevien politiikkamuutosten tiedontarpeen suurempana kuin neuvonta ja monimuotoisuuden edistämisen tiedontarpeen suurempana kuin virkamiehet/päätöksentekijät. Tiedontarve kotimaisen tuotannon asemasta globaalissa kehityksessä oli päätöksentekijöiden ja neuvojien mielestä suurempaa kuin itse yrittäjien mielestä.

Keskeisimpinä esteinä ilmastonmuutostiedon kiinnostavuudelle ja käytäntöön viemiselle maaseutuyrittäjän näkökulmasta nostettiin kaikissa ammattiryhmissä ristiriitainen tieto ja uskottavuus, tietotulva, ennakkoasenteet, nykyinen maatalouden tulotaso ja kannattavuus, asian kaukaisuus ja ilmiön globaalisuus. Myös omien vaikutusmahdollisuuksien hahmottamisen puute, vastakkainasettelu maatalouden ja ympäristönhoidon välillä, vaikeaselkoinen politiikka, muutoksen hitaus ja kokemus viljelijöiden syyllistämisestä ilmastonmuutoksen osatekijänä vähensivät ilmastonmuutoksen kiinnostavuutta. Maaseutuyrittäjät itse kokivat heillä olevan tällä hetkellä paljon oleellisempia ja kiireellisempiä asioita ratkaistavana kuin ilmastonmuutokseen varautuminen. Ilmastonmuutoksen vaikutukset nähtiin hitaina ja suhteellisen vähän nykypäivänä vaikuttavina (poikkeuksiakin tosin oli, kuten toteamat satoriskien lisääntymisestä). Nostettiin esiin myös maatalouden pitkää historiaa ja osoitettua kykyä sopeutua tarvittaessa hyvinkin erilaisiin sään muutoksiin. Päätöksentekijät nostivat hieman yrittäjiä useammin positiiviset näkökohdat ilmastonmuutokseen varautumisessa esiin. Näitä ehdotettiin löytyvän mm. uusituvan energian kehittämisestä ja muista tilojen kannattavuutta tai omavaraisuutta ja siten panostuotantoriippuvuutta vähentävistä ratkaisuista, uusista viljelykasveista, tekniikoista ja menetelmistä, kehittyneistä tilojen taloudellisen suunnittelun välineistä ja toimijoiden innostamisesta innovatiivisten esimerkkien kautta. Ammattiryhmävertailussa neuvojat kokivat keskimäärin maaseutuyrittäjien ilmastonmuutokseen liittyvät tiedontarpeet muita ryhmiä suuremmiksi. Arvio kokonaistiedontarpeesta (laskettuna ehdotettujen 65 ilmastonmuutoksen suoriin tai epäsuoriin vaikutuksiin liittyvän tiedontarveaiheen kiinnostavuuden keskiarvona) oli neuvojilla 3,03 (asteikko 1 (ei tiedon tarvetta) - 4 (erittäin suuri tiedon tarve)), kun se oli virkamies/päätöksentekijäryhmässä 2,96 ja maaseutuyrittäjillä 2,75. 


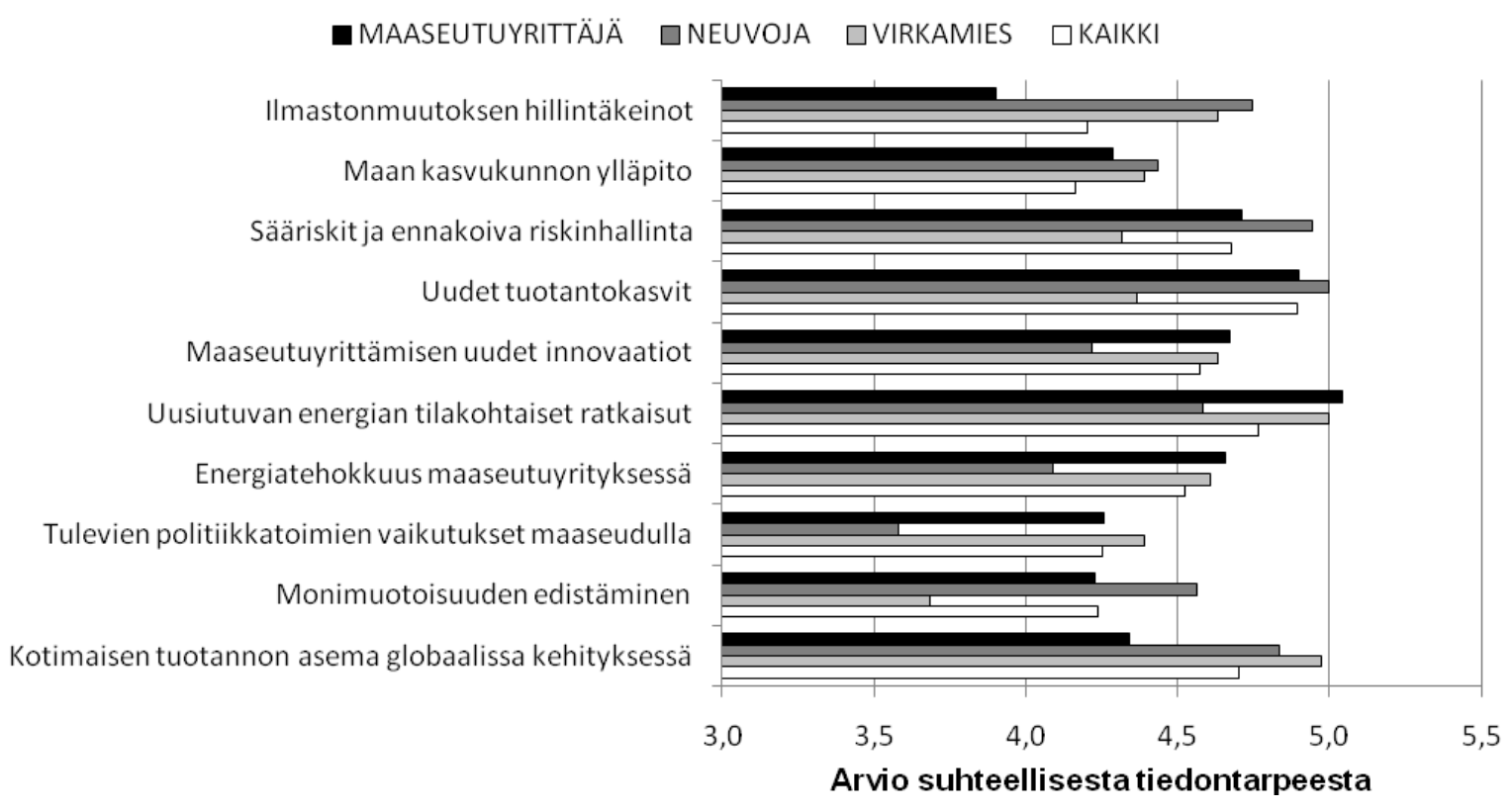

Kuva 1. Käsitykset maaseutuyrittäjän suhteellisista tiedontarpeista esitetyistä kymmenestä ilmastonmuutossidonnaisesta teemasta. Vastaajia pyydettiin järjestämään kymmenen esitettyä teemaa tärkeysjärjestykseen asteikolla 1-10 (arvo 1: vähiten tiedontarvetta, arvo 10: eniten tiedontarvetta) ja keskiarvo kuvaa teeman saamaa tärkeysarvoa suhteessa kaikkiin esitettyihin teemoihin. Luokitteluryhmässä maaseutuyrittäjä $n=70$, neuvoja $n=55$, virkamies $n=41$ ja kaikki $n=206$.

Vahvimpana kannustimena maaseutuyrittäjälle miettiä ilmastonmuutosta osana nykypäivän käytännön toimintaa pidettiin kytkemistä taloudellisiin vaikutuksiin eli tilan tuloihin ja kannattavuuteen. Toisaalta myös tuotannon kestävyydestä ja kestävästi tuotetun ruoan arvostuksesta, ympäristövaikutusten vähentämisestä, tulevista sukupolvista ja hyvistä innovatiivisista käytännön esimerkeistä löytyi monille vastaajille kannustimia. Koettiin että ilmastonmuutoksesta voidaan myös hyötyä kun aktivoidutaan nykyisestä kannattavuustilanteesta pohtimaan ennakoivaa sopeutumista keinona parantaa kannattavuutta ja kehittää tuotantoa. Vanhojen viljelyperiaatteiden kuten viljelymaan kunnon ylläpidon, viljelykierron, omavaraisuuden ja viljelytaidon kehittämisen mainittiin parantavan omia mahdollisuuksia kehittää tuotantoa tulevaisuudessa tuotanto-olojen ja kannattavuuden vaihdellessa yhä enemmän. Ilmastonmuutoksen mahdollisia hyötyjä ja aikaisen varautumisen etuja painottaviin tilaisuuksiin koettiin halua tulla. Erittäin tärkeänä pidettiin myös politiikan ja päätöksenteon edustajien mukanaoloa.

Keskeisimpiin ilmastotutkimuksen tiedonvälityksen ongelmiin sekä maailmalla että meillä liittyy tutkimustiedon hajanaisuus, laajuus ja ilmastomallien epävarmuus (Sterman 2011). Epävarmuus ilmastonmuutoksen vaikutuksista ja niiden paikallisuudesta ja ajankohdasta on syytä tiedostaa ja sitä pyrkiä pienentämään tutkimuksen avulla, mutta sitäkin tärkeämpää on korostaa että epävarmuus ei poista tarvetta varautua vaan pikemmin lisää sitä entisestään (Fischhoff 2011). Varautuminen monenlaisiin ja äkillisiinkin muutoksiin on yhä oleellisempaa. Laaja-alaista sopeutumiskykyä (Engle 2011) ja monipuolisuutta maataloudessamme (Lin 2011) tarvitaan siis ilmastonmuutokseen varautumisessa kohdennettujen sopeutumistoimien ohella.

Median vaikutus ihmisten asenteisiin on suuri. Ilmastonmuutoksen politisoinnin uskotaan vähentäneen Yhdysvaltojen väestön viimeaikaista uskoa siihen, miten yhtä mieltä tutkimus on ilmastonmuutoksen todellisuudesta (Pidgeon \& Fischhoff 2011). Kyselymme osoitti samanlaisia viitteitä ilmastonmuutoksen uutisoinnin suhteen Suomessa. "Infoähky", "ristiriitainen tieto ja asenteet" ja "ilmiön käsittely liian globaalisti ja kaukaisena asiana" mainittiin heikentävinä tekijöinä omalle nykypäivän ilmastonmuutokseen varautumiselle. Ihmisten tapa hahmottaa tulevaisuutta voi olla myös satunnaisten tapahtumien ohjaamaa ja nopeasti vaihtelevaa. Li ym. (2011) havaitsivat jopa kyselypäivän sään helteisyyden tai kylmyyden vaikuttaneen kansalaisten käsitykseen ilmastonmuutoksen todenmukaisuudesta: helteellä useammat uskoivat ilmaston muuttuvan kuin viileällä säällä.

Kyselymme perusteella maaseutuyrittäjistä löytyy hyvin eritavoin toimivia ja ajattelevia vastaajia: aktiivisesti tietoa hakevia, jatkuvaa kehittymistä ja uusia markkinamahdollisuuksia hakevia ja 
ilmastonmuutostiedosta avoimesti kiinnostuneita viljelijöitä löytyy kuten myös heitä, joita on mahdoton saada koulutustilaisuuksiin ilman velvoitteita. Mikäli maatalouden rakennekehitys Suomessa jatkuu viime vuosien kaltaisena eli tilakoko suurenee ja tilojen lukumäärä vähentyy, on tärkeää saada etenkin kasvavat tilat mukaan keskusteluun ilmastonmuutoksen mahdollisuuksista ja haasteista. Tilojen mahdollisuuksista varautua ja hyötyä esimerkiksi viljelykasvivalikoiman ja tuotannon monipuolistamisesta, uusiutuvan energian hyödyntämisestä ja yhteistyöverkostoista kaivataan käytännön esimerkkejä erilaisilta tiloilta, kokoluokasta ja päätuotantosuunnasta toiseen. Parhaat sopeutumistoimet eroavat usein alueittain ja jopa tilan ominaisuuksista riippuen, mutta esimerkeistä voi olla ideoitavissa hyviä ratkaisuja pienellä lisätyöllä.

Maaseutuyrittäjät toivoivat ilmastonmuutostiedon olevan pitävää tutkimustietoa vastakohtana ristiriitaisille epävarmuuksien raportoimiselle, kytkeytyvän tilan talouteen ja olevan useamman toimijatahon kanssa keskusteltua. Tutkijoiden ja viljelijöiden vuoropuhelua heikentää tutkimustiedon vaativuus ja käytännön sovellettavuuden vaikea hahmottaminen jos esitettyä informaatiota ei ole mietitty toimijan näkökulmasta eikä vapaaseen keskusteluun ole mahdollisuutta (Clarke 2003). ILMASE-hankkeessa on keskeisenä tavoitteena ollut lähteä liikkeelle maaseutuyrittäjien lähtökohdista. Hanke välittää ajantasaista asiantuntijatietoa, mutta perustellusti mietittyjen vuorovaikutuksellisten tiedonvälitystapojen avulla (kuten Pidgeon \& Fischhoff 2011). Hanke on lähtenyt liikkeelle kohderyhmän tiedontarpeiden ja ilmastotiedon kiinnostavuutta haittaavien tai parantavien tekijöiden arvioinnilla ja toimijaverkoston kokoamisella. Hankkeen alueellisiin työpajoihin kutsutaan mukaan käytännönläheisyyttä korostaen asiantuntijoita alustamaan ja maaseudun toimijoita laajasti keskustelemaan. Aineistojen kokoaminen nettisivustolle jatkaa teemoista keskustelua ja tuo aineistot edelleen laajemman yleisön saataville helposti lähestyttäviksi kokonaisuuksiksi suodatettuna. Vuorovaikutuksen onnistumista selvitetään hankkeessa tutkimuksellisesti yhteistyössä yhteiskuntatieteilijöiden kanssa. Hankkeen toivotaan paitsi lisäävän ilmasto- ja ympäristötietoisuutta maaseudulla niin myös herättävän toimintaa tiloilla. Tärkeässä roolissa on myös tutkimuksen tiedonsaanti käytännön tiedontarpeista ja tietoaukoista, mikä auttaa suuntamaan jatkotutkimusta yhä käytännönläheisemmäksi tulevaisuudessa.

\section{Johtopäätökset}

Tiedonvälitys ja vuoropuhelu päätöksentekijöiden ja käytännön toimijoiden kanssa on yhä keskeisempi osa tutkimuksen tekemistä. Vuorovaikutus testaa ja parantaa tutkimuksen käytännöllisyyttä ja nopeuttaa tulosten hyödyntämistä. Maaseutuyrittäjät ovat monitaitoisia oman arkensa ammattilaisia, ja tarvitsevat siihen sidoksissa olevia käytännön esimerkkejä ilmastonmuutokseen varautumisen tarpeiden hahmottamiseen. Kansainvälisesti laadukkaan, mutta meidän oloihimme sovelletun ilmastonmuutostutkimustiedon aikainen hyödyntäminen käytännön elinkeinojen kehittämisessä on oleellista maaseutumme elinvoiman varmistamiseksi tulevaisuudessakin. Ilmastonmuutoskommunikaation tulee rakentua parhaalle käytettävissä olevalle ilmastonmuutosasiantuntijuudelle, mutta vuorovaikutteisesti päätöksenteon ja toimijoiden kanssa. Ilmastonmuutosta ei voi tarkastella vain biofysikaalisten vaikutusten osalta vaan sisältäen myös taloudellisten, sosiaalisten ja poliittisten tekijöiden yhdysvaikutukset ja erilaisia hillinnän ja sopeutumisen vaihtoehtoja pohtien. Vuorovaikutusta eri toimijatasojen välillä tarvitaan kun halutaan varautua ilmastonmuutokseen ajoissa ja kokonaisvaltaisesti. ILMASE-hanke kutsuu maaseudun toimijat laajasti mukaan vaikuttamaan omaan tulevaisuuteensa. Lisätietoja toiminnasta löytyy hankkeen nettisivuilta: www.ilmase.fi

\section{Kirjallisuus}

Clarke, B. 2003. Report: Farmers and scientists. A case study in facilitating communication. Science Communication 25: 198-203.

Engle, N.L. 2011. Adaptive capacity and its assessment. Global Environmental Change 21: 647-656.

Fischhoff, B. 2007. Nonpersuasive communication about matters of greatest urgency: Climate change. Environmental Science \& Technology 41: 7204-7208.

Fischhoff, B. 2011. Applying the science of communication to the communication of science. Climatic Change 108: $701-705$ 
Kimpanpää, M. (toim.) 2009. Finland's Fifth National Communication under the United Nations Framework Convention on Climate Change. Ministry of the Environment and Statistics Finland, Helsinki. $280 \mathrm{~s}$.

Kriss, P.H., Loewenstein, G., Wang, X. \& Weber, R.A. 2011. Behind the veil of ignorance: Self-serving bias in climate change negotiations. Judgment and Decision Making 6: 602-615.

Li, Y., Johnson, E.J. \& Zaval, L. 2011. Local warming: Daily temperature change influences belief in global warming. Psychological Science 22: 454-459.

Lin, B.B. 2011. Resilience in agriculture through crop diversification: Adaptive management for environmental change. BioScience 61: 183-193.

Maa- ja metsätalousministeriö. 2011. Maa- ja metsätalousministeriön ilmastonmuutokseen sopeutumisen toimintaohjelma 2011-2015. Huoltovarmuutta, kestävää kilpailukykyä ja riskinhallintaa. Maa- ja metsätalousministeriö, $\quad$ huhtikuu $2011 . \quad$ Verkkojulkaisu: http://www.mmm.fi/attachments/mmm/julkaisut/muutjulkaisut/5yZhPxNpC/MMM_n_ilmastonmuutoksen_sopeutumi sen_toimintaohjelma.pdf

Pidgeon, N. \& Fischhoff, B. 2011. The role of social and decision sciences in communicating uncertain climate risks. Nature Climate Change 35-41.

Sterman, J.D. 2011. Communicating climate change risks in a skeptical world. Climatic Change 108: 811-826.

Tavoni, A., Dannenberg, A., Kallis, G. \& Löschel, A. 2011. Inequality, communication, and the avoidance of disastrous climate change in a public goods game. Proceedings of the National Academy of Sciences of the USA 108: 11825-11829. 